Proc. Estonian Acad. Sci. Biol. Ecol., 2002, 51, 1, 26-44

\title{
Mean zooplankter weight as a characteristic feature of an aquatic ecosystem
}

\author{
Juta Haberman and Helen Künnap
}

Võrtsjärv Limnological Station, Institute of Zoology and Botany, Estonian Agricultural University, 61101 Rannu, Tartumaa, Estonia; juta@zbi.ee; helenk@ut.ee

Received 7 November 2001, in revised form 15 January 2002

\begin{abstract}
The mean zooplankter weight is largely shaped by the trophic state of the water body. At the same time, it reflects even relatively slight differences in the trophy of lakes. In moderately eutrophic Lake Peipsi the mean zooplankter weight is $4.4 \mu \mathrm{g}$ and in strongly eutrophic Lake Vorrtsjärv, $2.7 \mu \mathrm{g}$. The mean cladoceran weight is 28 and $10 \mu \mathrm{g}$, the mean copepod weight 10 and $6.7 \mu \mathrm{g}$, the mean rotifer weight 0.9 and $0.6 \mu \mathrm{g}$, respectively. For individuals of the gen. Daphnia the mean weight is 52 and $30 \mu \mathrm{g}$, and for individuals of the gen. Bosmina, 21 and $7 \mu \mathrm{g}$, respectively. The average zooplankter of moderately eutrophic L. Peipsi is considerably larger compared with the average zooplankter of strongly eutrophic L. Võrtsjärv. Therefore, the zooplankton in L. Peipsi is in a far better condition than in L. Võrtsjärv and it can play its role in the transfer of energy from the algae to the fish more efficiently. Correlation analysis shows that the mean zooplankter weight is mainly built by the cladocerans and rotifers. The relationship between the mean weight of the individual and water temperature is more pronounced for L. Võrtsjärv and less pronounced for L. Peipsi where the amount of coexisting planktonic animals with different temperature requirements is larger. Also, the relationship between the mean weight and water biogen content is more clearly expressed in strongly eutrophic L. Võrtsjärv than in L. Peipsi, which has still retained some characteristics of a mesotrophic lake. Mean zooplankter weight characterizes both the zooplankton community and the whole ecosystem of the water body. Indirectly, it characterizes the animal groups dominating in zooplankton, feeding relationships between phyto- and zooplankton and between zooplankton and fish, as well as the pressure of fish on zooplankton and the trophy of the water body. Mean zooplankter weight can be used as a marker characteristic in the qualification of the ecosystem of the water body.
\end{abstract}

Key words: mean zooplankter weight, moderately eutrophic lake, strongly eutrophic lake.

\section{INTRODUCTION}

The mean zooplankter weight is shaped mainly by the trophic state of the water body and by the pressure of fish. It is known that the mean zooplankter weight decreases with increasing trophy. In strongly eutrophic water bodies large 
zooplankters will be replaced by small forms (Gulati, 1983; Manca et al., 1992; Havens, 1994; Andronikova, 1996; Welker \& Walz, 1999; Jeppesen et al., 2000). A study of Danish lakes of different trophy showed that a rise of the trophic level (total phosphorus (TP) content from $<0.05$ to $0.4 \mathrm{mg} \mathrm{P} \mathrm{L}^{-1}$ ) was accompanied with a decrease in the mean zooplankter weight from 5.1 to $1.5 \mu \mathrm{g}$. This was caused by a decline in the abundance of large-sized zooplankters (Daphnia spp., calanoids). The share of Daphnia spp. in the biomass of the cladoceran group decreased from 63-70\% to 30\% (Jeppesen et al., 2000). In Loosdrecht Lakes (The Netherlands) the average weight of a crustacean decreased with eutrophication from 20 to $18 \mu \mathrm{g}$ and that of a rotifer from 1 to $0.8 \mu \mathrm{g}$ (Gulati, 1984). The mean rotifer weight was especially small ( $0.1 \mu \mathrm{g}$ and even less) also in eutrophic lakes of Poland in summer (Karabin \& Ejsmont-Karabin, 1993). Strongly eutrophic L. Võrtsjärv, too, is characterized by the disappearance of large-sized Bosmina berolinensis Imhof, Cyclops kolensis Lilljeborg, and Eudiaptomus gracilis (Sars), which determine to a great extent the mean zooplankter weight and which were relatively abundant in the 1960s. The abundance of rotifers and Chydorus sphaericus Müller has undergone an increase (Haberman, 1998). Smith \& Gilbert (1995) claim that the toxins of the cyanobacteria dominating in strongly eutrophic waters (Microcystis aeruginosa) suppress the growth of cladocerans, whose measurements remain smaller.

Inorganic seston, floating in water, is thought to considerably impair the feeding and development of cladocerans as a consequence of which their mean weight decreases (Kirk \& Gilbert, 1990; Kirk, 1991). Since the seston content of water in L. Võrtsjärv is large (Nõges \& Haberman, 1985), its detrimental effect on filtrating cladocerans is highly probable.

Because fish always feed selectively, preferring larger food objects, their role in the formation of the mean zooplankter weight is great. In the case of the pressure of fish, large zooplankters are eaten up, and dominance is gained by small forms (Hülsmann et al., 1999; Karjalainen et al., 1999; Hoffman et al., 2001). In L. Peipsi too, smelt and vendace prefer large-sized cladocerans (Daphnia galeata Sars, Limnosida frontosa Sars, B. berolinensis, Leptodora kindti (Focke), E. gracilis). The Peipsi populations of smelt, vendace, and young perch can consume about $400000 \mathrm{t}$ of cladocerans and copepods (among them 66\% of cladocerans) during a vegetation period (Ibneeva, 1983).

The mean zooplankter weight affects significantly the nature of the food chain in a water body, doing this primarily through the capacity of zooplankton to filtrate phytoplankton. The larger is the zooplankter, the more powerful grazer it is (Carpenter \& Kitchell, 1992). Elser \& Goldman (1990), Carney \& Elser (1990), and Jeppesen et al. (1999) also claim that zooplankton's grazing pressure on phytoplankton is strong in mesotrophic lakes, dominated by large-sized species of the genus Daphnia, and weak in eutrophic waters dominated by small-sized zooplankters.

On the basis of scales for the assessment of trophy (Milius, 1991; Milius et al., 1991, 1994), L. Peipsi is eutrophic, while L. Võrtsjärv is a strongly eutrophic water body and, considering its chlorophyll content, it can even be considered hypertrophic. 
The mean zooplankter weight is a relatively informative characteristic of the zooplankton community as well as of the whole ecosystem of a water body.

The aim of the present study was to find out:

1. how the relatively small difference in trophy between the studied lakes (both being eutrophic) is reflected in their mean zooplankter weight; and

2. whether the mean zooplankter weight can be used as a marker characteristic in the qualification of the ecosystems of these constantly monitored lakes.

\section{MATERIAL AND METHODS}

The material for the present paper was collected monthly from the pelagial of L. Peipsi and biweekly from the pelagial of L. Võrtsjärv during the vegetation periods of 1997-2000. Samples were taken with a quantitative Juday net of $85 \mu \mathrm{m}$ mesh from one monitoring station in L. Võrtsjärv and from four stations in L. Peipsi. One-litre samples for analysing rotifers were collected with a Ruttner sampler. Altogether more than 500 quantitative zooplankton samples were analysed. The samples were preserved in $4 \%$ formaldehyde solution and studied by conventional quantitative analysis. At least 20 individuals of each zooplankton species were measured in each sample. The individual weights of rotifers were estimated from the average lengths according to Ruttner-Kolishko (1977). The lengths of crustaceans were converted to weights according to Studenikina \& Cherepakhina (1969, nauplii) and Balushkina \& Winberg (1979, other groups). The mean zooplankter weight was calculated from individual zooplankter weights. Spearman's rank correlation tests and regression analysis were used to evaluate the relationships between the mean zooplankter weight and some abiotic and biotic characteristics of the ecosystems of the studied lakes.

\section{DESCRIPTION OF THE STUDY SITES}

Lake Peipsi s.l. $\left(3558 \mathrm{~km}^{2}\right)$ is located on the border of Estonia and Russia. Lake Peipsi s.l. (Chudskoe ozero in Russian) consists of three parts: the largest and deepest northern part L. Peipsi s.s., the middle strait-like part L. Lämmijärv (Teploe), and the southern part L. Pihkva (Pskovskoe). The present paper deals only with L. Peipsi s.s. Lake Võrtsjärv is situated in central Estonia (Fig. 1). Lake Peipsi is considered a lake of moderate eutrophy, while L. Võrtsjärv is a strongly eutrophic water body. The Emajõgi River flows out of L. Võrtsjärv and discharges into L. Peipsi. Table 1 presents some data on the studied lakes.

In L. Peipsi, Aulacoseira islandica (O. Müller) Sim. is characteristic of the phytoplankton in the cool period; A. granulata (Ehr.) Sim. and Stephanodiscus binderanus (Kütz.) Krieger prevail in summer and autumn. Gloeotrichia echinulata (J. S. Smith) P. Richter and Aphanizomenon flos-aquae (L.) Ralfs dominate in summer causing algal blooms. The average summer biomass of the 


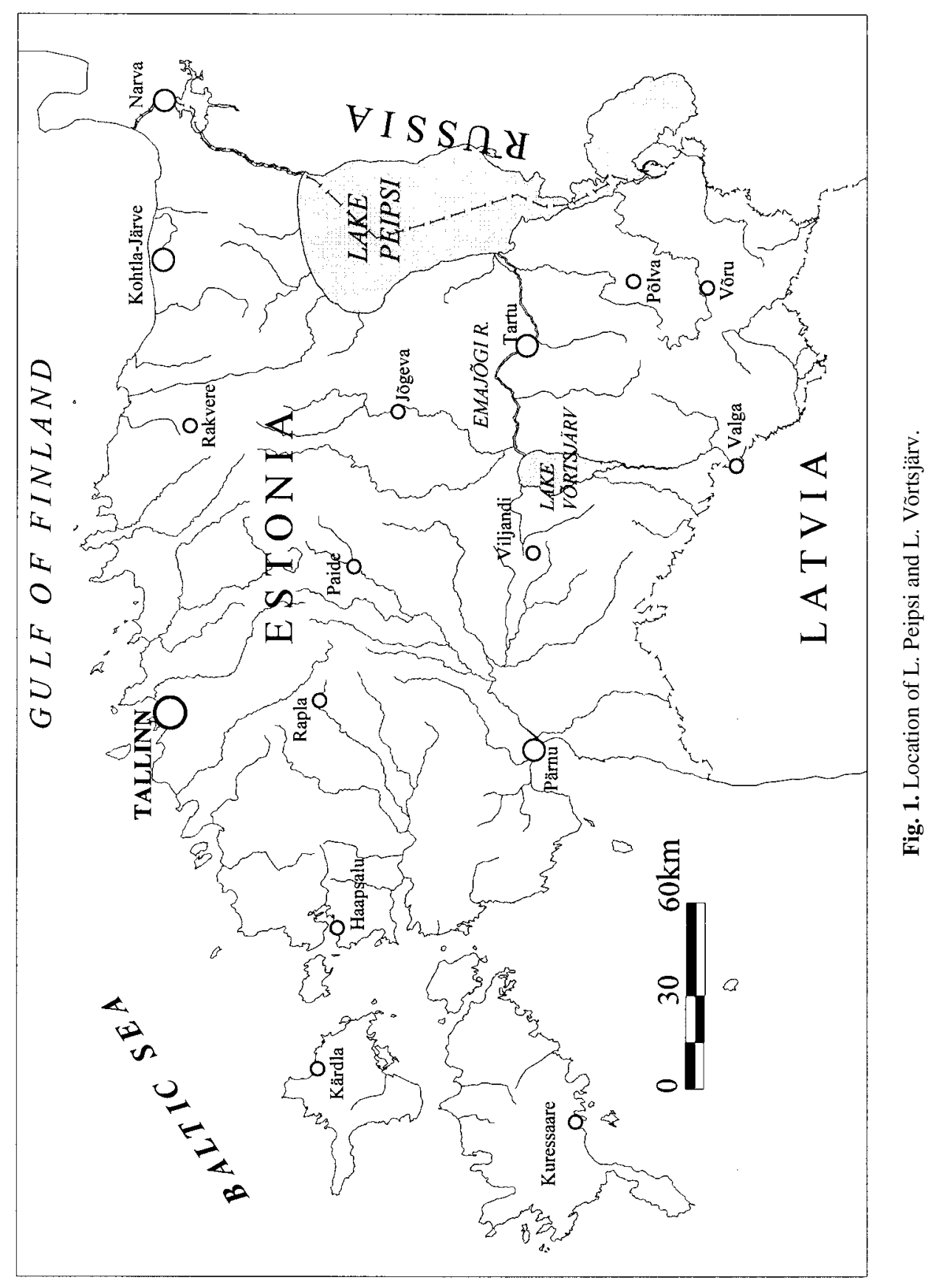


Table 1. Data on L. Peipsi s.s and L. Võrtsjärv

\begin{tabular}{lcc}
\hline & L. Peipsi s.s. & L. Võrtsjärv \\
\hline Area, $\mathrm{km}^{2}$ & 2611 & 270 \\
Volume, $\mathrm{km}^{3}$ & 21.79 & 0.75 \\
Mean depth, m & 8.3 & 2.8 \\
Maximum depth, m & 12.9 & 6.0 \\
Length, km & 81 & 34.8 \\
Transparency, m & 2.2 & 1.1 \\
pH & 8.28 & $7.5-8.8$ \\
Total P, mg P m & 35 & 54 \\
Total N, mg N m & & 1600 \\
Chl, $\mathrm{mg} \mathrm{m}^{-3}$ & 678 & 22
\end{tabular}

phytoplankton fluctuates between 3 and $15 \mathrm{~g} \mathrm{~m}^{-3}$, being below $10 \mathrm{~g} \mathrm{~m}^{-3}$ in most years (Laugaste et al., 1996). The species serving as food objects of suitable size for mesozooplankton make up about 22\% (Nõges et al., 1993).

In L. Võrtsjärv, the algal community is represented by an association of filamentous algae, species of the genus Aulacoseira in spring, Limnothrix planktonica (Wolosz.) Meffert, Planktolyngbya limnetica (Lemm.) Kom.-Legn., L. redekei (Van Goor) Meffert, and Aphanizomenon skujae Kom.-Legn. et Cronb. in summer and in autumn, accompanied with a variable low biovolume of small algae, mostly chlorophytes and chrysophytes. Phytoplankton biomass fluctuates widely - from some milligrams in winter up to 100 grams per cubic metre in summer. During the last decade the biomass seldom exceeded $30 \mathrm{~g} \mathrm{~m}^{-3}$. Water blooms are a common phenomenon (Nõges \& Laugaste, 1998). The species serving as food of suitable size for zooplankton account for about 12\% (Nõges et al., 1998).

In L. Peipsi the mean zooplankton numbers in the vegetation period fluctuate between $46 \times 10^{3}$ and $2752 \times 10^{3}$ ind. $\mathrm{m}^{-3}$, with an average of $974 \times 10^{3}$ ind. $\mathrm{m}^{-3}$; the biomass ranges between 0.088 and $6.344 \mathrm{~g} \mathrm{~m}^{-3}$. The mean summer biomass is on average $3.044 \mathrm{~g} \mathrm{~m}^{-3}$ (Haberman, 2001). In L. Võrtsjärv the zooplankton numbers fluctuate in the range $168-4048 \times 10^{3}$ ind. $\mathrm{m}^{-3}$, the average being $1181 \times 10^{3}$ ind. $\mathrm{m}^{-3}$; the biomass varies from 0.126 to $2.579 \mathrm{~g} \mathrm{~m}^{-3}$. The mean summer biomass is on average $2.078 \mathrm{~g} \mathrm{~m}^{-3}$. Zooplankton numbers are higher, while biomass is lower in L. Vorrtsjärv compared with L. Peipsi. This is to be expected, taking into account the differences in the trophic state of the lakes.

In L. Peipsi the main commercial fishes are smelt, perch, ruffe, roach, bream, and pike, up to the 1990s also vendace and lately, pikeperch. The total catch of fish has usually been $9000-12000 \mathrm{t}\left(25-34 \mathrm{~kg} \mathrm{ha}^{-1}\right)$ a year (Pihu, 1996). In L. Võrtsjärv bream, eel, pikeperch, and pike are the most important commercial fishes. Planktophagous smelt is not abundant. In the 1950s, vendace was a commercial fish, but its numbers have significantly decreased due to the eutrophication of the lake. The total catch of fish is $435 \mathrm{t}\left(16.1 \mathrm{~kg} \mathrm{ha}^{-1}\right)$ (Pihu, 1998). 


\section{RESULTS}

To facilitate the understanding of the difference in the mean zooplankter weight between L. Peipsi and L. Võrtsjärv, a table was compiled of the species dominating in zooplankton biomass (Table 2).

Figure 2 shows the dynamics of the mean zooplankter weight in moderately eutrophic L. Peipsi and in strongly eutrophic L. Võrtsjärv for the vegetation period of 1997-2000. The mean zooplankter weight in L. Peipsi ranged from 1.1 (May)

Table 2. Dominating zooplankton species in the biomass of zooplankton in L. Peipsi and L. Võrtsjärv

\begin{tabular}{|c|c|c|}
\hline Month & L. Peipsi & L. Võrtsjärv \\
\hline May & $\begin{array}{l}\text { Bosmina berolinensis Imhof, } \\
\text { copepodites }\end{array}$ & $\begin{array}{l}\text { Keratella cochlearis (Gosse), } \\
\text { gen. Polyarthra (P. dolichoptera } \\
\text { Idelson }+P \text {. luminosa (Kutikova)), } \\
\text { Bosmina longirostris (Müller) }\end{array}$ \\
\hline June & $\begin{array}{l}\text { B. berolinensis, copepodites, } \\
\text { Daphnia galeata Sars, } \\
\text { D. cristata } \text { Sars, } \\
\text { D. cucullata } \text { Sars }\end{array}$ & $\begin{array}{l}\text { Chydorus sphaericus Müller, } \\
\text { copepodites }\end{array}$ \\
\hline July & $\begin{array}{l}\text { D. galeata, D. cucullata, } \\
\text { D. cristata, Diaphanosoma } \\
\text { brachyurum (Liéven), } \\
\text { Limnosida frontosa Sars, } \\
\text { Leptodora kindti (Focke), } \\
\text { Bythotrephes longimanus Leydig, } \\
\text { Eudiaptomus gracilis (Sars), } \\
\text { copepodites }\end{array}$ & $\begin{array}{l}\text { C. sphaericus, } \\
\text { D. cucullata, } \\
\text { copepodites }\end{array}$ \\
\hline August & D. cucullata, copepodites & $\begin{array}{l}\text { C. sphaericus, } \\
\text { D. cucullata, } \\
\text { copepodites, } \\
\text { P. luminosa }\end{array}$ \\
\hline September & $\begin{array}{l}\text { B. berolinensis, } \\
\text { Bosmina } \text {. coregoni Baird, } \\
\text { Bosmina gibbera Schoedler, } \\
\text { D. galeata, } \\
\text { copepodites }\end{array}$ & $\begin{array}{l}\text { C. sphaericus, } \\
\text { copepodites, } \\
\text { Asplanchna priodonta Gosse }\end{array}$ \\
\hline October & $\begin{array}{l}\text { B. berolinensis, B. c. coregoni, } \\
\text { B. gibbera, D. galeata, } \\
\text { E. gracilis, copepodites }\end{array}$ & $\begin{array}{l}\text { C. sphaericus, } \\
\text { B. longirostris }\end{array}$ \\
\hline November & B. berolinensis, E. gracilis & $\begin{array}{l}\text { B. c. coregoni, } \\
\text { B. longirostris, } \\
\text { gen. Polyarthra (P. dolichoptera }+ \\
\text { P. luminosa) }\end{array}$ \\
\hline
\end{tabular}




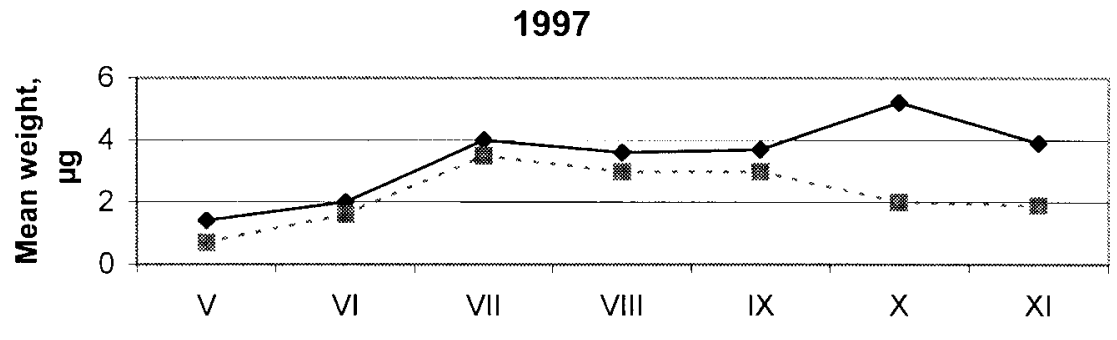

Month

1998

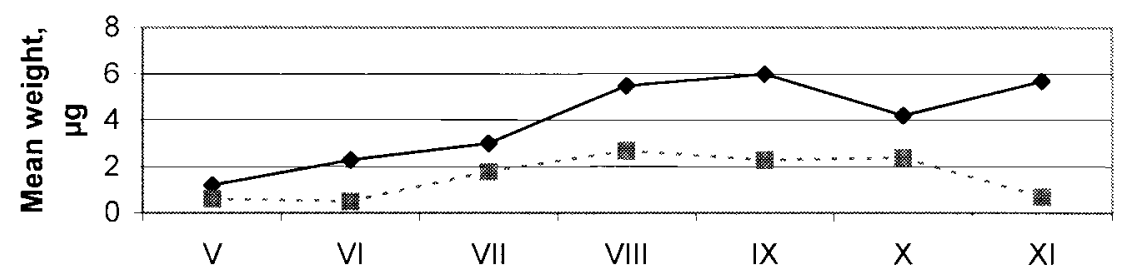

Month

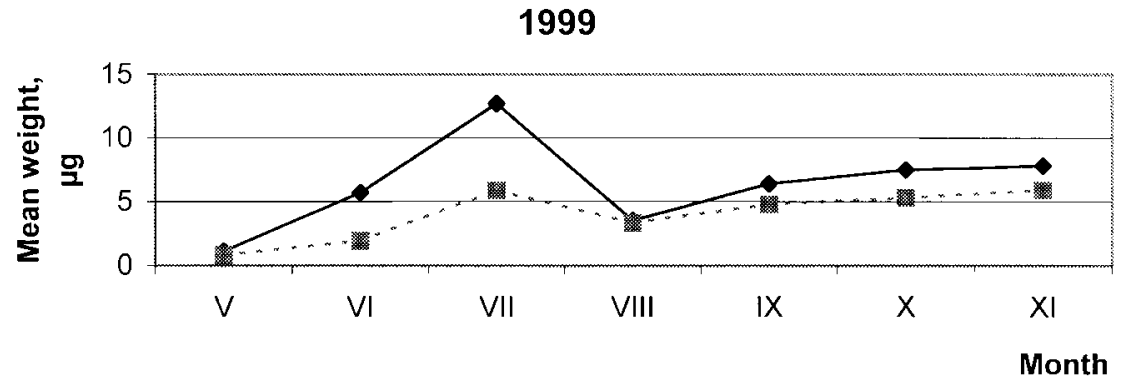

2000

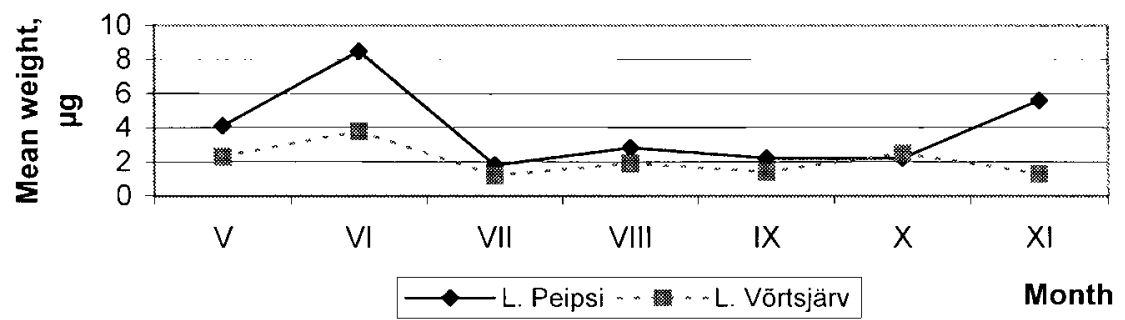

Fig. 2. Mean zooplankter weight in 1997-2000. 
to $12.7 \mu \mathrm{g}$ (July) with an average of $4.4 \mu \mathrm{g}$. Similar results have been obtained also from earlier investigations (1985-86, 1992-96), where the mean zooplankter weight varied between 0.8 and $10 \mu \mathrm{g}$ with an average of $4 \mu \mathrm{g}$ (Haberman, 2001). The mean zooplankter weight in L. Võrtsjärv ranged from 0.5 (June) to $5.9 \mu \mathrm{g}$ (July, November) with an average of $2.7 \mu \mathrm{g}$. The zooplankter of L. Võrtsjärv is considerably smaller than the zooplankter of L. Peipsi, which is confirmed also by earlier data (Haberman, 1997). In both lakes, the zooplankter size is the smallest in May when the share of rotifers (\%) in zooplankton is large. In L. Peipsi the zooplankter size may be the largest in June, July, September, and in October-November when large zooplankters are dominating (see Table 2). The peak in the curve of the dynamics of the mean zooplankter weight in L. Võrtsjärv is mainly caused by the abundant occurrence of Daphnia cucullata and adult specimens of the genus Mesocyclops in plankton.

Figure 3 displays the dynamics of the mean weight of a rotifer, a cladoceran, and a copepod for the vegetation period of 1997-2000. The mean rotifer weight is $0.9 \mu \mathrm{g}$ in L. Peipsi and $0.6 \mu \mathrm{g}$ in L. Võrtsjärv. In L. Peipsi the mean rotifer weight is the smallest in June, because at this time zooplankton is dominated by the abundant small-sized Conochilus unicornis Rousselet, Keratella cochlearis, and Polyarthra dolichoptera. The largest mean weight occurs in October when Asplanchna priodonta attains a peak occurrence for the vegetation period. The rotifer of L. Võrtsjärv is the smallest in July when plankton is dominated by the indicators of eutrophy Anuraeopsis fissa (Gosse), Keratella tecta (Gosse), and Trichocerca rousseleti (Voigt). The large rotifers Brachionus calyciflorus Pallas and A. priodonta are more frequent in the cool period than in summer, which is also reflected in the dynamics of the mean rotifer weight in L. Võrtsjärv.

A cladoceran is significantly larger in L. Peipsi than in L. Võrtsjärv. The mean cladoceran weight for the vegetation period is $28 \mu \mathrm{g}$ in L. Peipsi and $10 \mu \mathrm{g}$ in L. Võrtsjärv. This difference in the mean weights can be explained by the size of dominating species (see Table 2).

As among the copepods of both lakes the juvenile forms (copepodites) from the genus Mesocyclops (mainly M. leuckarti (Claus) and M. oithonoides (Sars)) are dominating, the mean copepod weights are relatively similar: $10 \mu \mathrm{g}$ in L. Peipsi and $6.7 \mu \mathrm{g}$ in L. Võrtsjärv. The difference is related to the large calanoid Eudiaptomus gracilis, which has almost disappeared from L. Võrtsjärv but dominates in L. Peipsi.

Figure 4 shows the mean weight of a zooplankter from the genera Daphnia and Bosmina. The mean weight of both these zooplankters is significantly larger in L. Peipsi than in L. Võrtsjärv, which can be explained by the dominating species in either genus. The mean weight of Daphnia in L. Peipsi is determined by D. galeata $(30-80 \mu \mathrm{g})$, D. cucullata Sars $(40-50 \mu \mathrm{g})$, and D. cristata $(30-40 \mu \mathrm{g})$. In L. Võrtsjärv D. cucullata is the only representative of the genus Daphnia, dominating there in biomass but having a smaller size $(25-35 \mu \mathrm{g})$ than in L. Peipsi. The mean Daphnia weight is $52 \mu \mathrm{g}$ in L. Peipsi and $30 \mu \mathrm{g}$ in L. Võrtsjärv. In L. Peipsi the genus Bosmina is represented by 10 species (Haberman, 2001). At the same time, in L. Võrtsjärv this genus includes practically only two species 
(a)

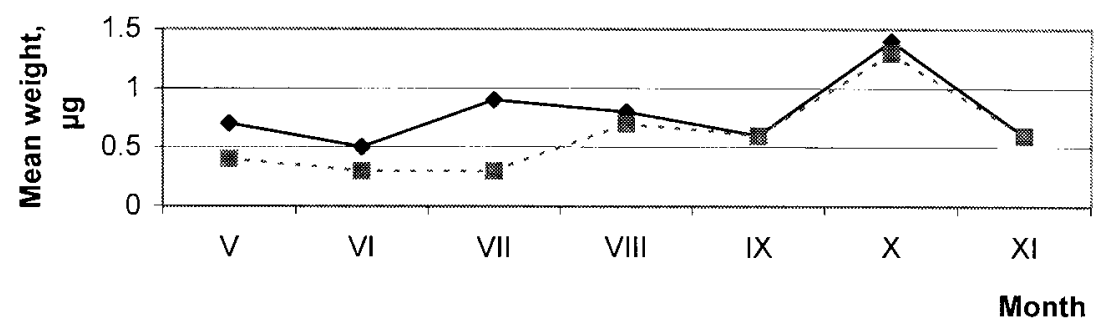

(b)

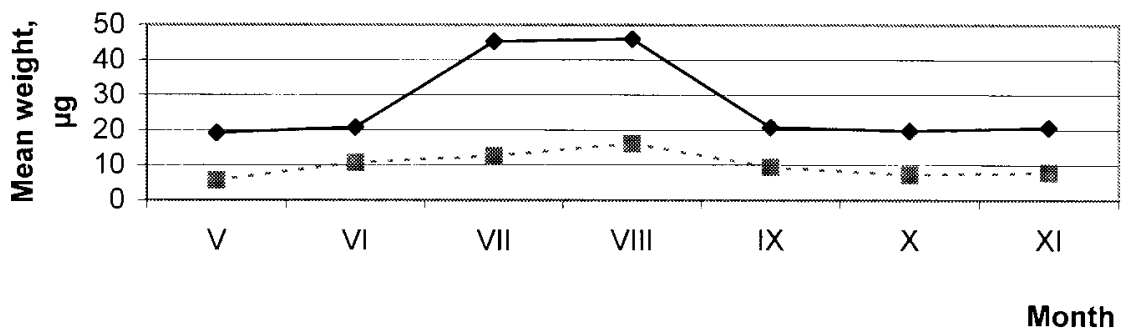

(c)

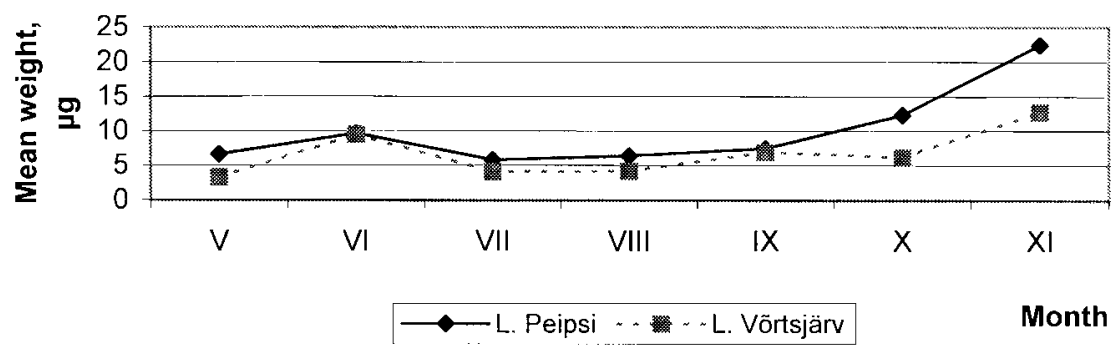

Fig. 3. Mean rotifer weight (a), mean cladoceran weight (b), and mean copepod weight (c) in 1997-2000.

(B. c. coregoni and B. longirostris), because the species preferring mesotrophic water (B. berolinensis, B. obtusirostris Sars) have almost disappeared from this strongly eutrophied lake (Haberman, 1998). In L. Peipsi the mean Bosmina weight is primarily built of large dominating B. berolinensis $(54 \mu \mathrm{g})$, whereas in L. Võrtsjärv it is greatly determined by small B. longirostris $(5-7 \mu \mathrm{g})$. The mean weight of a zooplankter from the genus Bosmina is $21 \mu \mathrm{g}$ in L. Peipsi and $7 \mu \mathrm{g}$ in L. Võrtsjärv. 
(a)

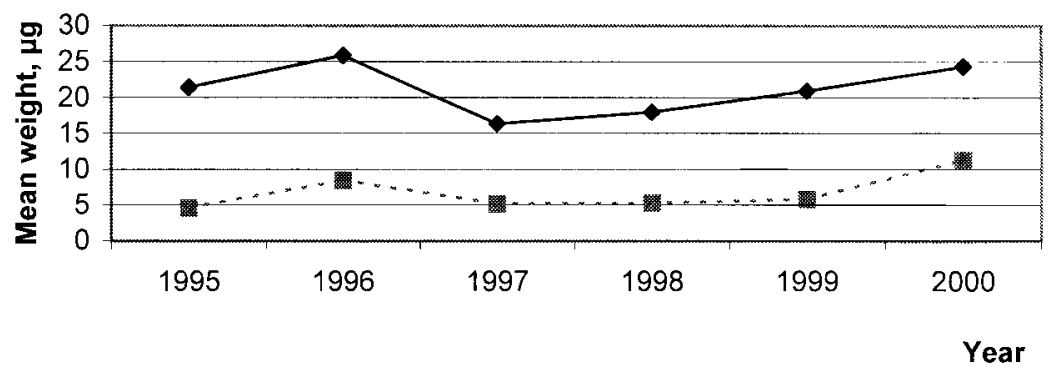

(b)

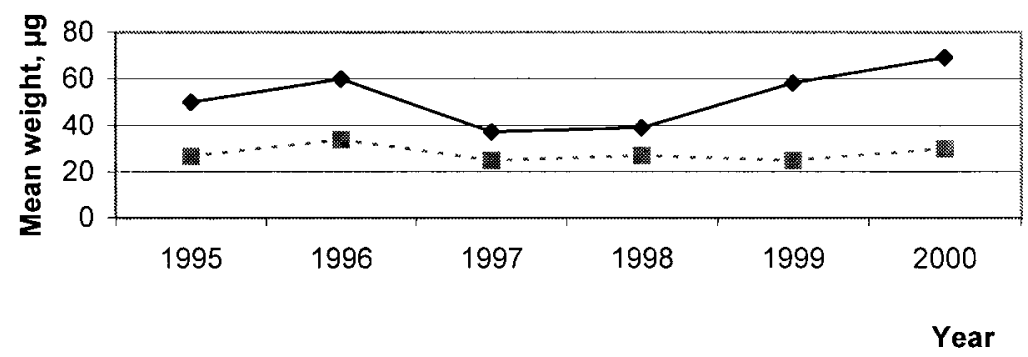

$\longrightarrow$ L. Peipsi $n$ * n L. Võrtsjärv

Fig. 4. Mean Bosmina (a) and Daphnia weight (b) in 1995-2000.

It is interesting to add that in winter the zooplankter of L. Peipsi is also significantly larger compared with the zooplankter of L. Võrtsjärv: $1.2 \mu \mathrm{g}$ and $0.7 \mu \mathrm{g}$, respectively. The winter plankton of L. Peipsi is frequently represented by the large copepods E. gracilis and Cyclops kolensis Lilljeborg, which have disappeared from L. Võrtsjärv owing to the high trophic level of this lake. The larger mean weight of the rotifers of L. Peipsi can be attributed also to the occurrence of the large-sized rotifer Notholca cinetura Skorikov (lacking in L. Võrtjärv) in its winter plankton.

In both studied lakes the mean zooplankter weight $\left(W_{\mathrm{ZP}}\right)$ was positively correlated with the biomass of cladocerans (L. Peipsi: $r=0.652, n=66, P<0.001$; L. Võrtsjärv: $r=0.76, n=59, P<0.001$ ), which was to be expected considering cladoceran size. There was a positive correlation between $W_{\mathrm{ZP}}$ and the biomass of the genus Daphnia $(r=0.773, n=21, P<0.001)$ in L. Peipsi (Fig. 5) while in L. Võrtsjärv $W_{\mathrm{ZP}}$ was positively correlated with the biomass of Chydorus sphaericus $(r=0.47, n=59, P<0.001)$. Table 2 shows the important role of the 


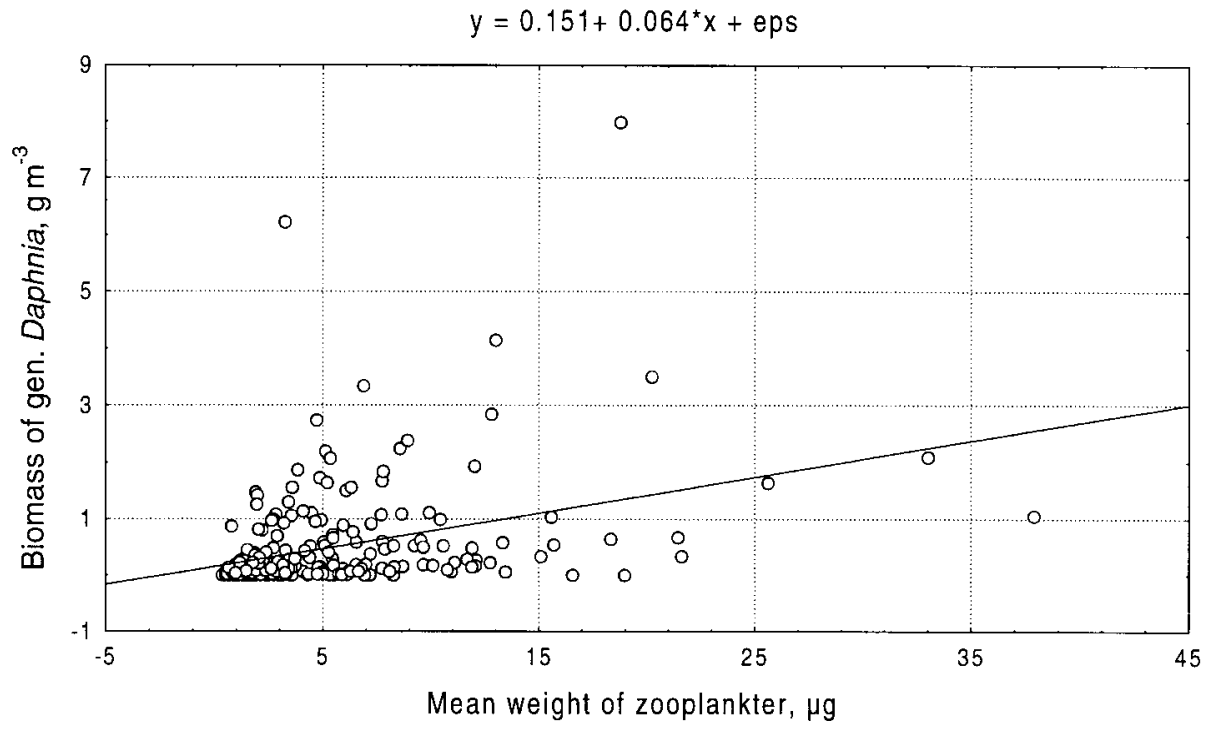

Fig. 5. Relationship between the mean zooplankter weight and biomass of gen. Daphnia in L. Peipsi.

genus Daphnia in the zooplankton of L. Peipsi and of C. sphaericus in L. Vorrtsjärv. In strongly eutrophic L. Võrtsjärv, where the proportion of rotifers in zooplankton is large, $W_{\mathrm{ZP}}$ is negatively correlated with the abundance $(r=-0.73$, $n=59, P<0.001)$ and biomass of rotifers $(r=-0.57, n=59, P<0.001)$ as well as with the abundance of zooplankton $(r=-0.51, n=59, P<0.001)$ built primarily of rotifers. In moderately eutrophic L. Peipsi, where the amount of rotifers is smaller than in L. Võrtsjärv, negative correlations with the rotifer characteristics were weaker. Nevertheless, a relatively strong negative correlation $(r=-0.568, n=66, P<0.001)$ between $W_{\mathrm{ZP}}$ and the percentage of rotifers in zooplankton abundance (Fig. 6). There was a negative correlation also between $W_{\mathrm{ZP}}$ and the number of veligers of Dreissena polymorpha $(r=-0.381, n=56$, $P<0.001)$ in L. Peipsi and between $W_{\mathrm{ZP}}$ and the biomass of nauplii of copepods $(r=-0.51, n=59, P<0.001)$ in L. Võrtsjärv. It is also interesting to note a negative correlation $(r=-0.522, n=66, P<0.001)$ between $W_{\mathrm{ZP}}$ and the ratio of zooplankton to phytoplankton biomass $\left(B_{\mathrm{ZP}} / B_{\text {Phyt }}\right)$, characterizing the level of trophy, in L. Peipsi. For this lake, which is at a transition stage from mesotrophy to eutrophy, no significant correlations were found between $W_{\mathrm{ZP}}$ and the biogen content of water. However, for L. Võrtsjärv, a weak negative correlation occurred between the mean cladoceran weight and the content of total nitrogen in water $\left(r=-0.32, n=59, P<0.001\right.$; Fig. 7). In L. Võrtsjärv, $W_{\mathrm{ZP}}$ showed a weak negative correlation $(r=-0.48, n=59, P<0.001)$ with water transparency, which is an indicator of the trophy of water. In L. Peipsi, $W_{\mathrm{ZP}}$ did not reveal any significant correlation with water temperature, whereas in L. Võrtsjärv the mean 


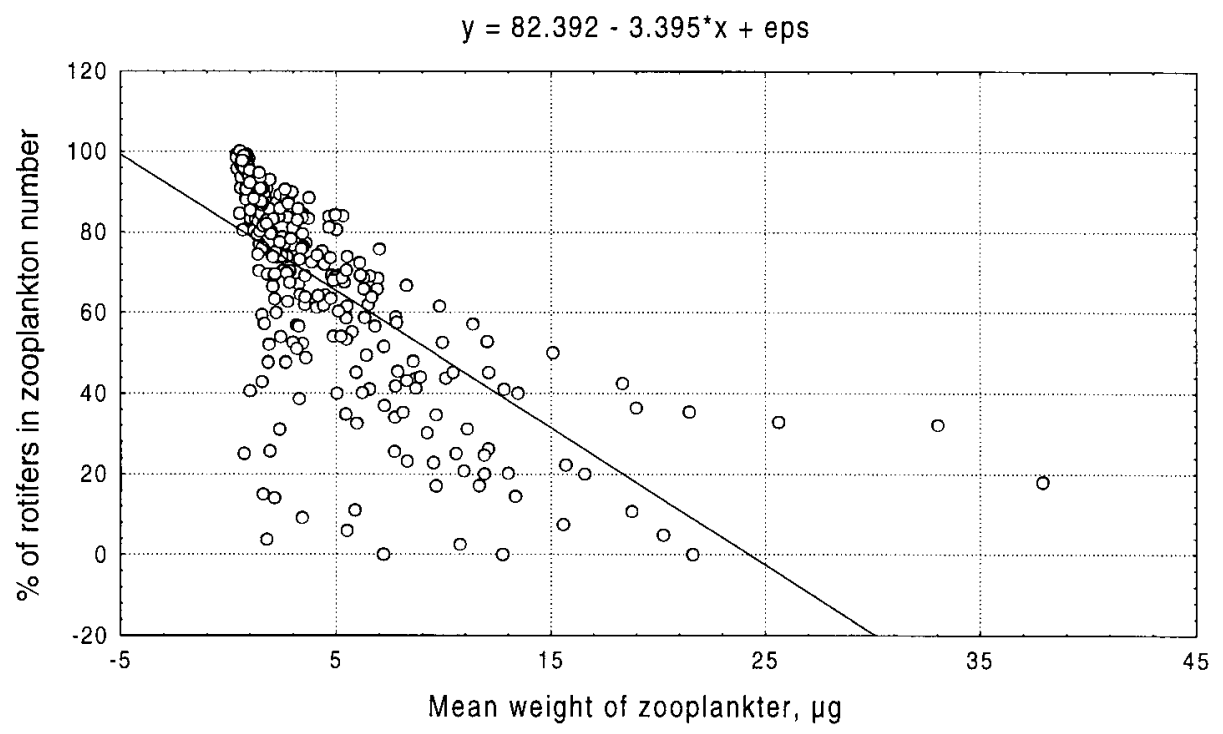

Fig. 6. Relationship between the mean zooplankter weight and the percentage of rotifers in the zooplankton number in L. Peipsi.

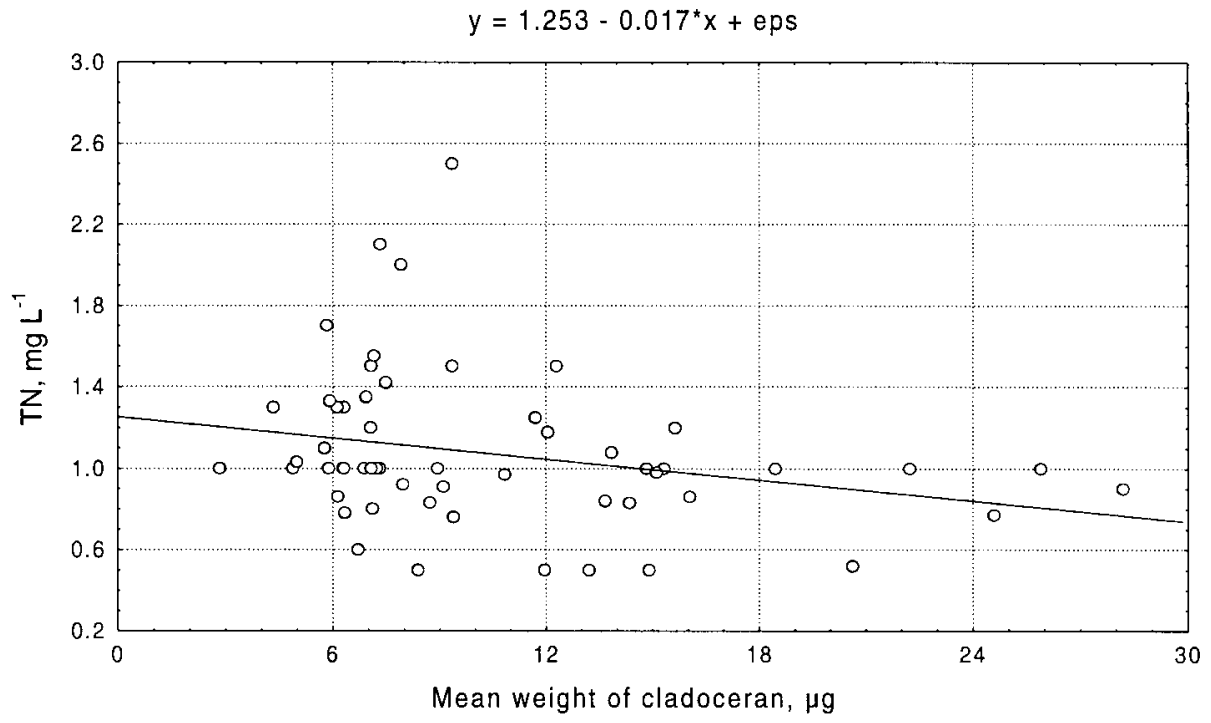

Fig. 7. Relationship between the mean cladoceran weight and the content of total nitrogen in the water of L. Võrtsjärv. 
cladoceran weight was positively correlated $(r=0.47, n=59, P<0.001)$ and the mean rotifer weight was negatively correlated $(r=-0.41, n=59, P<0.001)$ with water temperature. In L. Peipsi zooplankters with different temperature requirements coexist in the vegetation period, but the zooplankters of L. Võrtsjärv are predominantly thermophilic. The main determinant of the mean cladoceran weight in L. Võrtsjärv, D. cucullata, is among the most thermophilic zooplankters. The negative correlation between the mean rotifer weight and water temperature can be explained by the circumstance that in summer, at the time of the highest water temperature, the small-sized Anuraeopsis fissa, Keratella tecta, and Trichocerca rousseleti are the main dominants in zooplankton. At low water temperatures, however, the mean rotifer weight is determined by the larger forms - Asplanchna girodi Guerne, Brachionus calyciflorus Pallas, and Synchaeta verrucosa Nipkow.

\section{DISCUSSION}

\section{Mean zooplankter weight}

The mean zooplankter weight reflects adequately the trophic state of a water body. It is known to decrease with increasing trophy, as then zooplankton will be dominated by small zooplankters - rotifers and small crustaceans (Gulati, 1990; Karabin \& Ejsmont-Karabin, 1993; Havens, 1994). This is caused by changes in zooplankton's food, the algae. When the trophic level of a water body rises, then, contrary to zooplankton, phytoplankton will be dominated by large filamentous algae, primarily cyanobacteria, which are not suitable food for zooplankters (Augusti et al., 1991). As a result, large zooplankters, feeding on algae, start to disappear gradually from the water body, and plankton will be dominated by small zooplankters feeding on bacteria and detritus. This process has already taken place in strongly eutrophic L. Võrtsjärv (Haberman, 1998) but not yet in L. Peipsi (Table 2). Large algal feeding Daphnia galeata, Bosmina berolinensis, and Eudiaptomus gracilis, dominating in L. Peipsi, have disappeared from L. Võrtsjärv owing to its high trophy (B. berolinensis, E. gracilis), or have never existed in this lake (D. galeata). B. berolinensis is a species of oligo-mesotrophic waters. Its abundant occurrence gives evidence of the relatively good state of L. Peipsi as well as of its being a moderately eutrophic water body. The average weight of a female B. berolinensis in L. Peipsi is $54 \mu \mathrm{g}$ (Haberman, 2001). Also $D$. galeata tends to be a species of oligo-mesotrophic waters and it does not thrive in eutrophic waters (Gulati, 1983; Korovchinsky, 2000). As D. galeata is a large zooplankter, with a mean weight of up to $80 \mu \mathrm{g}$ in L. Peipsi, its role in the formation of the mean zooplankter weight is often great. Individuals of Daphnia are not very fastidious about food and are able to consume food objects of different size (including bacteria), which serves as an advantage for them as filtrators (Kamjunke et al., 1999; Boersma \& Stelzer, 2000). Daphnia spp. are also known to feed on amorphous and soft colonial forms of Microcystis aeruginosa 
(Fulton \& Paerl, 1987). E. gracilis, on the contrary, is characterized by highly selective feeding: it prefers larger food objects (small algae) and cannot feed on bacteria (Lampert, 1992). In the 1950s and 1960s, E. gracilis was a dominant also in L. Võrtsjärv (Schönberg, 1961); however, by now it has practically disappeared from this strongly eutrophic lake (Haberman, 1998). E. gracilis has almost disappeared from eutrophic waters of The Netherlands as well (Gulati, 1983). Feeding on small algae, this species is regarded as an inhabitant of mostly oligo- and mesotrophic waters (Muck \& Lampert, 1984), whose abundance in a water body starts to decrease when the chlorophyll content of water exceeds $6 \mathrm{mg} \mathrm{m}^{-3}$ (Rognerud \& Kjellberg, 1984). In L. Võrtsjärv, the many-year water chlorophyll content in the vegetation period varies from 27 to $39 \mathrm{mg} \mathrm{m}^{-3}$ (Nõges et al., 1998), while in L. Peipsi its average content is $14.7 \mathrm{mg} \mathrm{m}^{-3}$ (Nõges et al., 1996). Gulati (1984) is of the opinion that the feeding of E. gracilis is successful only at food concentrations less than $1 \mathrm{~g} \mathrm{C} \mathrm{m}^{-3}$. The phytoplankton biomass in L. Võrtsjärv is $2.6 \mathrm{~g} \mathrm{C} \mathrm{m}^{-3}$ (Nõges \& Laugaste, 1998), in L. Peipsi s.s. $0.2-0.8 \mathrm{~g} \mathrm{C} \mathrm{m}^{-3}$ (Laugaste et al., 1996). The mean weight of a male E. gracilis is $40 \mu \mathrm{g}$ and that of females $59 \mu \mathrm{g}$ in L. Peipsi. E. gracilis is mainly represented with juvenile individuals $(20 \mu \mathrm{g})$. Scarce occurrence of adults (particularly large egg-carrying females) indicates the pressure of fish. According to the data of Andronikova (1996), Lake Ladoga, which was oligotrophic in the 1960s, is now strongly eutrophied, while the proportion of $E$. gracilis in zooplankton abundance has decreased from $17 \%$ to $2 \%$. Bosmina longirostris and Chydorus sphaericus, dominating in L. Võrtsjärv, are indicator species of eutrophy; Daphnia cucullata is abundant in eutrophic waters as well, but it is not so closely related to eutrophy as the two former species (Taleb et al., 1994; Hansen \& Christoffersen, 1995). The rise in the trophic level of L. Lago Maggiore (Italy) was also accompanied with an abundant occurrence of C. sphaericus (Manca et al., 1992).

As in 1996 the water level dropped to the lowest values ever recorded in L. Võrtsjärv, an abrupt increase in the mean zooplankter weight occurred. The annual mean water level was $43 \mathrm{~cm}$ below zero $(33.07 \mathrm{~m})$, i.e. $1 \mathrm{~m}$ lower than the long-term average (Järvet \& Nõges, 1998). The effect of water level fluctuations on the zooplankton community was evident (Põllumäe \& Haberman, 1998). The biomass of zooplankton was considerably larger in 1996 (in summer $2.34 \mathrm{~g} \mathrm{~m}^{-3}$ ) compared with $1995\left(1.52 \mathrm{~g} \mathrm{~m}^{-3}\right)$ and $1997\left(0.88 \mathrm{~g} \mathrm{~m}^{-3}\right)$. Also the characteristic zooplankton structure changed in L. Võrtsjärv in 1996. The percentage of cladocerans increased significantly in zooplankton biomass. In particular, the biomass and even the mean weight of Daphnia cucullata increased: from $27.6 \mu \mathrm{g}$ in 1995 to $33.1 \mu \mathrm{g}$ in 1996. As a result, the mean zooplankter weight increased as well (Fig. 8). The causes of changes in zooplankton were related to phytoplankton, i.e. food for zooplankton. Stronger sediment resuspension in 1996 enriched water with suspended solids and nutrients, resulting in a slight increase in the trophic state and more intensive phytoplankton growth (up to $72 \mathrm{~g} \mathrm{~m}^{-3}$ ) (Nõges et al., 1997). The lower water level improved light conditions by "cutting off" the less illuminated and less productive deep layers. This was probably one of the main factors causing the collapse of the domination of Limnothrix redekei and 


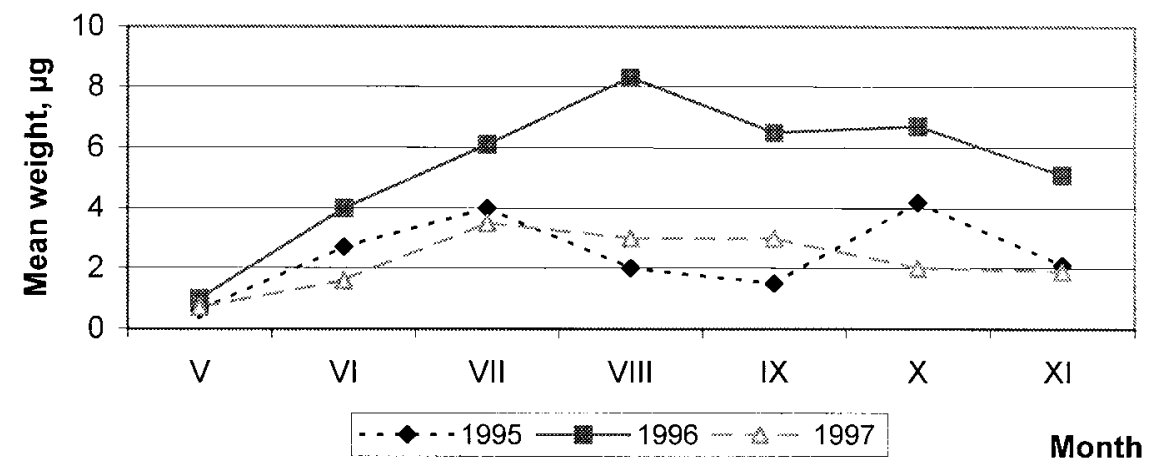

Fig. 8. Mean zooplankter weight in L. Võrtsjärv in 1995-97.

L. planktonica and initiating the mass development (max. $36 \mathrm{~g} \mathrm{~m}^{-3}$ ) of Cyanonephron styloides Hickel. Small-celled cyanobacteria represented a suitable food base for zooplankton, bringing about a change in the zooplankton community in 1996.

The mean zooplankter weight influences the whole zooplankton community and hence the links of the ecosystem in the water body. When dealing with the mean zooplankter weight for L. Peipsi and L. Võrtsjärv, it would be interesting to know the role that the zooplankton weight plays in the shaping of the food chain type. The ratio of the production of filtrative zooplankton $\left(P_{\text {Filt }}\right)$ to that of algae, i.e. to primary production $(P P)$, gives evidence of the food chain type as well as of the character of zooplankters' feeding. In L. Peipsi, the ratio $P_{\text {Fill }} / P P$ was 0.101 for the vegetation period in 1985-86 (Haberman, 1996). This means that about $10 \%$ of the energy of algae passes over to zooplankton; there is a direct relationship between the algae and zooplankton: zooplankton consumes living algae. In the lake the effective algal food chain prevails: algae $\rightarrow$ zooplankton $\rightarrow$ fish. Knowing which large filtrating zooplankters dominate in L. Peipsi (Table 2), this type of food chain is quite expected. In contrast, in strongly eutrophic L. Võrtsjärv, where the dominant small zooplankters (see Table 2) are not able to eat large algae and consume bacteria and detritus instead, only $2.1 \%$ of the energy of algae reaches zooplankton, the relatively ineffective microbial food chain dominates: algae $\rightarrow$ bacteria+detritus $\rightarrow$ zooplankton $\rightarrow$ fish (Haberman, 1998; Nõges et al., 1998). The larger is the filtering zooplankter, the more efficient is its feeding. The food ration of the filtrating zooplankter is directly determined by the mean zooplankter weight (Carpenter \& Kitchell, 1992; Sartonov, 1995). The species of the genus Daphnia (three species dominating in L. Peipsi, only one in L. Võrtsjärv) are powerful filtrators (Jürgens \& Stolpe, 1995; Arnèr et al., 1998). Correlation analysis revealed also a positive relationship between the mean zooplankter weight and grazing for both studied lakes (L. Peipsi: $r=0.5$; L. Võrtsjärv: $r=0.4, P<0.001$ ) (Haberman, 2001). The grazing of herbivorous zooplankton is one of the indicators of the lake's trophy (Gulati, 1990) and it 
decreases with increasing trophy. It should be noted that no late-spring clearwater phase was observed in L. Võrtsjärv (Nõges \& Nõges, 1998). However, in L. Peipsi a clear-water period was observed in June (Nõges et al., 1996). The clear-water phase in lakes is mainly caused by the genus Daphnia (Meijer et al., 1999; Scheffer \& Rinaldi, 2000). Evidence of the variable capacity of zooplankton as a consumer of algae in the studied lakes is provided also by the ratio of the food ration of herbivorous zooplankton to primary production $\left(C_{\mathrm{Filt}} / P P\right)$. In L. Peipsi the zooplankton's food ration formed $50 \%$ of primary production in 1985-86 and 34\% in 1997-98, whereas in L. Võrtsjärv it accounted only for $12 \%$ of primary production (Haberman, 1998; Nõges et al., 2001). Wetzel (1995) notes that utilization of more than half of primary production is a rare phenomenon and occurs only temporarily. Jeppesen et al. (2000) found that algal-feeding zooplankton consumes $59 \%$ of algal biomass per day in lakes of low trophy $\left(<0.05 \mathrm{mg} \mathrm{P} \mathrm{L}^{-1}\right)$, but $16-19 \%$ at the trophic level of $0.2-0.4 \mathrm{mg} \mathrm{P} \mathrm{L}^{-1}$. In L. Peipsi, $6 \%$ of the production (energy) of algae reaches fish, while in L. Võrtsjärv the corresponding proportion is only 3\% (Haberman, 1996, 1998). Transformation of phytoplankton production into fish production depends to a great extent on the trophy of the water body and can be hundreds of times more effective in oligotrophic than in hypertrophic waters (Downing et al., 1990).

The mean zooplankter weight characterizes both the zooplankton community and the whole ecosystem of the water body. Indirectly, it characterizes the animal groups dominating in zooplankton, feeding relationships between phyto- and zooplankton and between zooplankton and fish, as well as the pressure of fish on zooplankton and the trophy of the water body. The mean zooplankter weight can be used as a marker characteristic in the qualification of the ecosystem of the water body.

\section{ACKNOWLEDGEMENTS}

This research was partly supported by Contract No. EVK1-CT-2000-000076 Mantra-East. The authors would like to thank Mrs. Ester Jaigma for revising the English text of this paper.

\section{REFERENCES}

Andronikova, I. 1996. Zooplankton characteristics in monitoring of Lake Ladoga. Hydrobiologia, 322, 173-179.

Arnèr, M., Koivisto, S., Norberg, J. \& Kautsky, N. 1998. Trophic interactions in rockpool food webs: regulation of zooplankton and phytoplankton by Notonecta and Daphnia. Freshwater Biol., 39, 79-90.

Augusti, S., Duarte, C. \& Canfield, D. E. Jr. 1991. Biomass partitioning in Florida phytoplankton communities. J. Plankton Res., 13, 239-245.

Balushkina, E. V. \& Winberg, G. G. 1979. Dependence between the mass and length of the body in the case of plankton animals. In General Foundations of the Study of Aquatic Ecosystems (Winberg, G. G., ed.), pp. 169-172. Nauka, Leningrad (in Russian). 
Boersma, M. \& Stelzer, C.-P. 2000. Response of a zooplankton community to the addition of unsaturated fatty acids: an enclosure study. Freshwater Biol., 45, 179-188.

Carney, J. J. \& Elser, J. J. 1990. The strength of zooplankton-phytoplankton coupling in relation to trophic state. In Ecology of Large Lakes (Tilzer, M. M., ed.), pp. 616-631. New York.

Carpenter, S. R. \& Kitchell, J. F. 1992. Trophic cascade and biomanipulation: interface of research and management - a reply to the comment by DeMelo et al. Limnol. Oceanogr., 37, 208-213.

Downing, J. A., Plante, C. \& Lalonde, S. 1990. Fish production correlated with primary productivity, not the morphoedaphic index. Can. J. Fish. Aquat. Sci., 47, 1929-1936.

Elser, J. J. \& Goldman, C. R. 1990. Zooplankton effects on phytoplankton in lakes of contrasting trophic status. Limnol. Oceanogr., 36, 64-90.

Fulton, R. S. \& Paerl, H. W. 1987. Effects of colonial morphology on zooplankton utilization of algae resources during blue-green algal (Microcystis aeruginosa) blooms. Limnol. Oceanogr., 32, 634-644.

Gulati, R. D. 1983. Zooplankton and its grazing as indicators of trophic status in Dutch lakes. Envir. Monitor. Assessm., 3, 343-354.

Gulati, R. D. 1984. The zooplankton and its grazing as measures of trophy in the Loosdrecht Lakes. Verh. Int. Ver. Limnol., 22, 863-867.

Gulati, R. D. 1990. Zooplankton structure in the Loosdrecht Lakes in relation to trophic status and recent restoration measures. Hydrobiologia, 191, 173-188.

Haberman, J. 1996. Contemporary state of zooplankton in Lake Peipsi. Hydrobiologia, 338, 113-123.

Haberman, J. 1997. A comparative study of zooplankton in two large lakes of Estonia. Proc. Estonian Acad. Sci. Biol. Ecol., 46, 225-244.

Haberman, J. 1998. Zooplankton of Lake Võrtsjärv. Limnologica, 28, 49-65.

Haberman, J. 2001. Zooplankton. In Lake Peipsi. Flora and Fauna (Pihu, E. \& Haberman, J., eds.), pp. 50-68. Sulemees, Tartu.

Hansen, B. \& Christoffersen, K. 1995. Specific growth rates of heterotrophic plankton organisms in a eutrophic lake during a spring bloom. J. Plankton Res., 17, 413-430.

Havens, K. E. 1994. Experimental perturbation of a freshwater plankton community: a test of hypothesis regarding the effects of stress. Oikos, 69, 147-153.

Hoffman, J. C., Smith, M. E. \& Lehman, J. T. 2001. Perch or plankton: top-down control of Daphnia by yellow perch (Perca flavescens) or Bythotrephes cederstroemi in an inland lake? Freshwater Biol., 46, 759-775.

Hülsmann, S., Mehner, T., Worischka, S. \& Plewa, M. 1999. Is the difference in population dynamics of Daphnia galeata in littoral and pelagic areas of a long-term biomanipulated reservoir affected by age-0 fish predation. Hydrobiologia, 408/409, 57-63.

Ibneeva, N. I. 1983. Exploitation of food resources by planktophagous fishes in Lake PeipsiPihkva. Sb. nauchn. tr. GosNIORKh, 209, 44-50 (in Russian).

Järvet, A. \& Nõges, P. 1998. Lake water level. In Present State and Future Fate of Lake Võrtsjärv. Results from Finnish-Estonian Joint Project in 1993-1997 (Huttula, T. \& Nõges, T., eds.), pp. 18-21. The Finnish Environment, 209 (Pirkanmaa Regional Environment Centre, Tampere).

Jeppesen, E., Jensen, J. P., Søndergaard, M. \& Lauridsen, T. 1999. Trophic dynamics in turbid and clearwater lakes with special emphasis on the role of zooplankton for water clarity. Hydrobiologia, 408/409, 217-231.

Jeppesen, E., Jensen, J. P., Søndergaard, M., Lauridsen, T. \& Landkildehus, F. 2000. Trophic structure, species richness and biodiversity in Danish lakes: changes along phosphorus gradient. Freshwater Biol., 45, 201-218.

Jürgens, K. \& Stolpe, G. 1995. Seasonal dynamics of crustacean zooplankton, heterotrophic nanoflagellates and bacteria in a shallow, eutrophic lake. Freshwater Biol., 33, 27-38.

Kamjunke, N., Benndorf, A., Wilbert, C., Opitz, M., Kranich, J., Bollenbach, M. \& Benndort, J. 1999. Bacteria ingestion by Daphnia galeata in a biomanipulated reservoir: a mechanism stabilizing biomanipulation. Hydrobiologia, 403, 109-121. 
Karabin, A. \& Ejsmont-Karabin, J. 1993. Pelagic zooplankton of the Great Masurian Lakes. In Hydrobiological Station Mikolajki. Progress Report 1990-1991, pp. 22-28. Warszawa.

Karjalainen, J., Leppä, M., Rahkola, M. \& Tolonen, K. 1999. The role of benthivorous and planktivorous fish in a mesotrophic lake ecosystem. Hydrobiologia, 408/409, 73-84.

Kirk, K. L. 1991. Inorganic particles alter competition in grazing plankton: the role of selective feeding. Ecology, 72, 915-923.

Kirk, K. L. \& Gilbert, J. J. 1990. Suspended clay and the population dynamics of planktonic rotifers and cladocerans. Ecology, 71, 1741-1755.

Korovchinsky, N. M. 2000. Species richness of pelagic Cladocera of large lakes in the eastern hemisphere. Hydrobiologia, 434, 41-54.

Lampert, W. 1992. Zooplankton vertical migrations: implications for phytoplankton-zooplankton interactions. Arch. Hydrobiol. Beih., 35, 69-78.

Laugaste, R., Jastremskij, V. \& Ott, I. 1996. Phytoplankton of Lake Peipsi-Pihkva: species composition, biomass and seasonal dynamics. Hydrobiologia, 338, 49-62.

Manca, M. A., Colderoni, A. \& Mosello, R. 1992. Limnological research in Lago Maggiore: studies on hydrochemistry and plankton. Mem. Ist. Ital. Idrobiol., 50, 171-200.

Meijer, M.-L., DeBoois, I., Scheffer, M., Portielje, R. \& Hosper, H. 1999. Biomanipulation in shallow lakes in the Netherlands: an evaluation of 18 case studies. Hydrobiologia, 408/409, 13-30.

Milius, A. 1991. Chlorophyll $a$ in Estonian lakes. Proc. Estonian Acad. Sci. Biol., 40, 199-206.

Milius, A., Saan, T., Starast, H. \& Lindpere, A. 1991. Total phosphorus in Estonian lakes. Proc. Estonian Acad. Sci. Ecol., 1, 122-130.

Milius, A., Starast, H. \& Lindpere, A. 1994. Total nitrogen in small lakes of SE Estonia. Proc. Estonian Acad. Sci. Ecol., 4, 175-181.

Muck, P. \& Lampert, W. 1984. An experimental study on the importance of food conditions for the relative abundance of calanoid copepods and cladocerans. Arch. Hydrobiol. Suppl., 66, 157-179.

Nõges, P. \& Haberman, J. 1985. Zooplankton Võrtsjärve esmastoodangu kasutajana. In Kaasaegse ökoloogia probleemid (Frey, T., ed.), pp. 180-182. Tartu.

Nõges, P. \& Laugaste, R. 1998. Seasonal and long-term changes in phytoplankton of Lake Võrtsjärv. Limnologica, 28, 21-28.

Nõges, P., Nõges, T. \& Jastremskij, V. V. 1996. Primary production of Lake Peipsi-Pihkva. Hydrobiologia, 338, 77-89.

Nõges, P., Haberman, J., Zingel, P., Tammert, H. \& Nõges, T. 1997. Võrtsjärve seisund madalaveelisel 1996. aastal. In Kaasaegse ökoloogia probleemid (Frey, T., ed.), pp. 149-154. Tartu.

Nõges, T. \& Nõges, P. 1998. Primary production in Lake Võrtsjärv. Limnologica, 28, 29-40.

Nõges, T., Haberman, J., Timm, M. \& Nõges, P. 1993. The seasonal dynamics and trophic relations of the plankton components in Lake Peipsi (Peipus). Int. Rev. ges. Hydrobiol., 78, 513-519.

Nõges, T., Nõges, P., Haberman, J., Kisand, V., Kangur, K., Kangur, A. \& Järvalt, A. 1998. Food web structure in shallow eutrophic Lake Võrtsjärv (Estonia). Limnologica, 28, 115-128.

Nõges, T., Haberman, J., Kisand, V., Laugaste, R. \& Zingel, P. 2001. Trophic relations and food web structure of plankton community in Lake Peipsi s.s. In Lake Peipsi. Flora and Fauna (Pihu, E. \& Haberman, J., eds.), pp. 74-81. Sulemees, Tartu.

Pihu, E. 1996. Fishes, their biology and fisheries management in Lake Peipsi. Hydrobiologia, 338, $163-172$.

Pihu, E. 1998. Fishes and fisheries management in Lake Võrtsjärv. Limnologica, 28, 91-94.

Põllumäe, A. \& Haberman, J. 1998. The effect of fluctuating water level on the zooplankton of Lake Võrtsjärv, Central Estonia. Proc. Estonian Acad. Sci. Biol. Ecol., 47, 259-267.

Rognerud, S. \& Kjellberg, G. 1984. Relationships between phytoplankton and zooplankton biomass in large lakes. Verh. Int. Ver. Limnol., 22, 666-671.

Ruttner-Kolishko, A. 1977. Suggestions for biomass calculation of planktonic rotifers. Arch. Hydrobiol., 8, 71-76. 
Sartonov, A. 1995. Effects of Microcystis aeruginosa on interference competition between Daphnia pulex and Keratella cochlearis. Hydrobiologia, 307, 1-3.

Scheffer, M. \& Rinaldi, S. 2000. Minimal models of top-down control of phytoplankton. Freshwater Biol., 45, 265-283.

Schönberg, N. 1961. Über die Biologie einiger pelagischer Kopepodenarten im See Võrtsjärv. In Hydrobiological Researches II (Haberman, H., Veldre, I., Mäemets, A. \& Simm, H., eds.), pp. 159-193. Acad. Sci. Estonian SSR, Tartu (in Russian).

Smith, A. D. \& Gilbert, J. J. 1995. Relative susceptibility of rotifers and cladocerans to Microcystis aeruginosa. Arch. Hydrobiol., 132, 309-336.

Studenikina, E. I. \& Cherepakhina, M. M. 1969. Mean weight of basic zooplankton forms of the Azov Sea. Gidrobiol. zh., 5, 89-91 (in Russian).

Taleb, H., Reyes-Marchant, P. \& Lair, N. 1994. Effect of vertebrate predation on the spatiotemporal distribution of cladocerans in a temperate eutrophic lake. Hydrobiologia, 294, $117-128$.

Welker, M. \& Walz, N. 1999. Plankton dynamics in a river-lake system - on continuity and discontinuity. Hydrobiologia, 408/409, 233-239.

Wetzel, R. G. 1995. Death, detritus, and energy flow in aquatic ecosystems. Freshwater Biol., 33, 83-89.

\title{
Zooplankteri keskmine kaal kui veeökosüsteemi iseloomustaja
}

\author{
Juta Haberman ja Helen Künnap
}

Zooplankteri keskmist kaalu kujundab oluliselt veekogu troofsus. Ka suhteliselt vähe erineva troofsusega järvede puhul erineb see näitaja märgatavalt. Mõõdukalt eutroofses Peipsi järves on zooplankteri keskmine kaal 4,4, tugevalt eutroofses Võrtsjärves 2,7 $\mu \mathrm{g}$; vesikirbulistel (Cladocera) on isendi keskmine

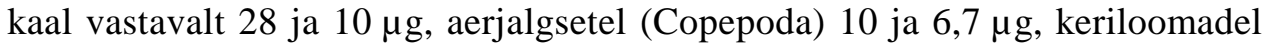
(Rotifera) 0,9 ja 0,6 $\mu \mathrm{g}$, perekonnal Daphnia 52 ja $30 \mu \mathrm{g}$ ning perekonnal Bosmina 21 ja $7 \mu \mathrm{g}$. Peipsi järve keskmine zooplankter on tunduvalt suurem Võrtsjärve omast. Seepärast on Peipsi järves zooplankton paremas seisundis kui Võrtsjärves ning täidab tõhusamalt oma osa energia ülekandmisel vetikatest kaladeni. Korrelatsioonianalüüs näitab, et zooplankteri keskmist kaalu kujundavad põhiliselt vesikirbulised ja keriloomad. Isendi keskmise kaalu ja veetemperatuuri seos ilmneb Võrtsjärves, kuid jääb nõrgaks Peipsi järves, kus elab kõrvuti rohkem erineva soojusnõudlusega planktoniloomi. Ka tuleb keskmise kaalu seos vee biogeenidesisaldusega paremini esile tugevalt eutroofses Võrtsjärves kui veel mõningate mesotroofse järve joontega Peipsis. Isendi keskmine kaal iseloomustab nii zooplanktoni kooslust kui ka kogu veekogu ökosüsteemi, kaudselt näitab see zooplanktonis domineerivaid loomarühmi, toitumissuhteid füto- ja zooplanktoni vahel ning zooplanktoni ja kalade vahel, kalade survet zooplanktonile ning veekogu troofsustaset. Zooplankteri keskmist kaalu võib kasutada ühe markertunnusena veekogu ökosüsteemi kirjeldamisel. 